$\overline{\overline{\text { 討 論 }}}$ (読者から著者へ)

\title{
『 $\mathbf{X}$ 線用アナライザの性能比較およびインバー夕装置測定に関する検討』 についての討論
}

\author{
（千田浩一，他，日放技学誌，48(4) 625-631（1992)） \\ 宮 崎茂・篠原文章・井手敏 典 \\ 上遠野昭
}

日本放射線技術学会東京部会 X線装置研究会

著者千田浩一先生へ

本会会誌第48巻第 4 号（1992年）に掲載されました上 記表題の論文につきまして次の 2 点についておたずね致 します。

1. Fig. 8,9,10 の KXO-50F における管電圧波形につ いて，貴論文は二次側で測定した管電圧波形を基準とし て各X線アナライザの比較を行っています。 その二次側 で測定した管電圧波形をみますと投入後約 $30 \mathrm{~ms}$ を境に 波形が変化しています。また Fig. 8，10においては，X 線アナライザで測定した波形とかなり異なる（怄が小さ くて細かい点を認識できませんがお互いの対応が一致し てないように見える）などしています。何か測定系の忠 実度に問題があるように思いますがいかがでしょうか。

ご参考までに当研究会で Fig. 8, 9, 10 と同一条件で測 定した同型装置の管電圧, 管電流, 蛍光強度波形を付図 致しました。

\section{使用測定器}

管電圧・管電流計 AB-2015D (トーレック株), 蛍光量 計 EY-1001D (トーレック株)

\section{オシロスコープ 7623A（SONY-TEKTRONICS）}

2. 本文 p. 629 下から12行目 (管電圧計は……このため 両者の管電圧測定值は，必ずしも一致するとは限らない と言える）と述べています。これから考えますと，测定 器によって異なる管電圧があり得ることになります。ど のような测定器であっても定義と異なる值を示すような ことは（测定器にとって）許されないことと存じます.

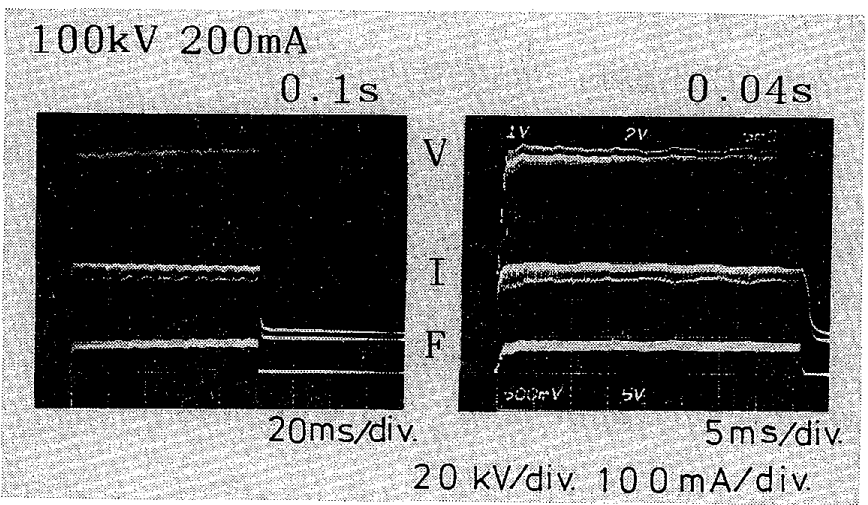

Fig. 1

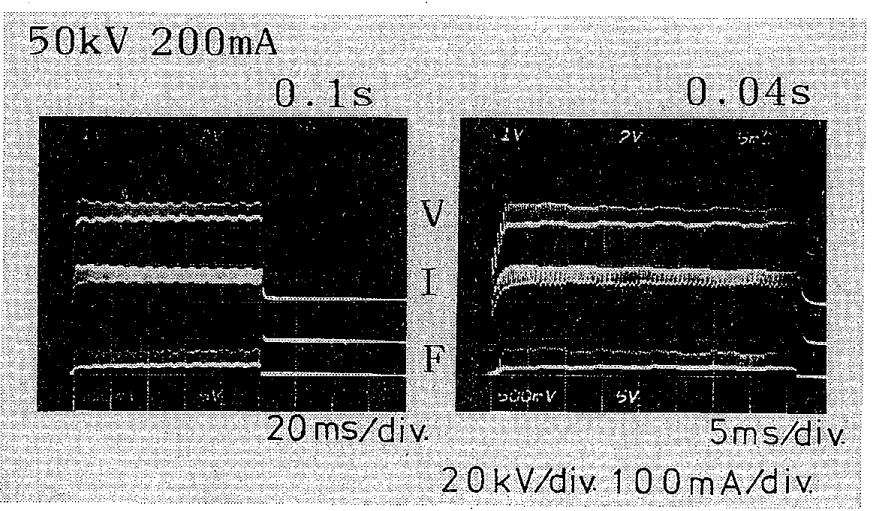

Fig. 2

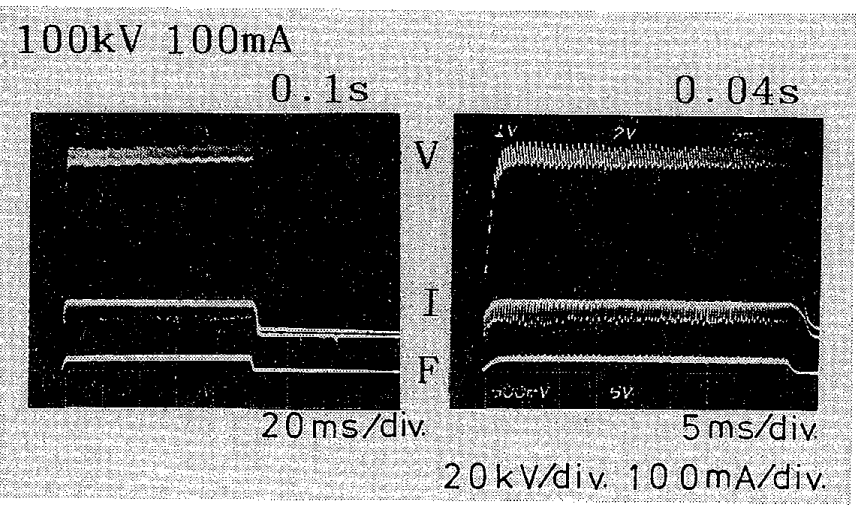

Fig. 3 